ISSN 0103-5150

Fisioter. Mov., Curitiba, v. 27, n. 3, p. 407-412, jul./set. 2014

Licenciado sob uma Licença Creative Commons

DOI: http://dx.doi.org.10.1590/0103-5150.027.003.A011

\title{
Effect of peripheral muscle fatigue during the testing of handgrip strength
}

\author{
Efeito da fadiga muscular periférica durante \\ o teste de força de preensão manual
}

\author{
Alex de Andrade Fernandes ${ }^{[a]}$, Ciro José Brito ${ }^{[b]}$, Breno Cesar Vieira ${ }^{[c]}$, João Carlos Bouzas Marins ${ }^{[\mathrm{d}]}$ \\ [a] PhD candidate, professor, Instituto Federal de Minas Gerais, Bambuí, MG - Brazil, e-mail: alex.andrade@ifmg.edu.br \\ [b] PhD, professor, Universidade Federal do Sergipe, Departamento de Educação Física, Aracaju, SE - Brazil, e-mail: \\ cirojbrito@gmail.com \\ [c] PhD candidate, professor, Instituto Federal do Sudeste de Minas Gerais, Setor de Educação Física., Barbacena, MG - Brazil, \\ e-mail: breno.vieira@ufv.br \\ [d] PhD, professor, Universidade Federal de Viçosa (UFV), Departamento de Educação Física, Viçosa, MG - Brazil, e-mail: \\ jcbouzas@ufv.br
}

\section{Abstract}

Introduction: Muscle fatigue is a phenomenon associated with physical work. It is common in endurance sports, physical fitness tests and daily activities. Some tests can be directly affected by the effect of peripheral muscle fatigue, including the handgrip strength (HGS) test, which is considered baseline measure for assessing the functionality of the hand. Objectives: a) verify the effect of peripheral muscle fatigue (between trials) during the testing of HGS, with a 60-second recovery interval; b) to analyze whether there is a difference in considering the mean value obtained in three trials or the best result as the final result. Materials and methods: The final sample comprised 1,279 men. We followed the standard methodology and used a hydraulic hand dynamometer. Results: There were statistically significant differences $(\mathrm{P}<0.05)$ in the dominant hand among all the trials: first ( $46.5 \pm 8.6 \mathrm{Kgf}$ ), second ( $46.4 \pm 8.5 \mathrm{Kgf}$ ) and third (46.1 $\pm 8.6 \mathrm{Kgf})$; and also in the non-dominant hand: first $(44.9 \pm 8.4 \mathrm{Kgf})$, second ( $44.5 \pm 8.3 \mathrm{Kgf})$ and third (44.0 $\pm 8.3 \mathrm{Kgf})$. We also found statistically significant differences $(\mathrm{P}<0.05)$ between the two ways of considering the final result. For the dominant hand, the mean of the three attempts was $46.3 \pm 8.3 \mathrm{Kgf}$ and the best result was $48.1 \pm 8.5 \mathrm{Kgf}$, whereas for the non-dominant hand, these results were $44.5 \pm 8.2 \mathrm{Kgf}$ and $46.0 \pm 8.2 \mathrm{kgf}$, respectively. Conclusion: Peripheral muscle fatigue directly interferes in the final result. A significant reduction in strength levels occurs in course of the assessment. The 
best result is frequently obtained at the first trial, which indicates that the highest value obtained should be considered as the final result.

Keywords: Muscle contraction. Muscle fatigue. Hand strength. Muscle strength dynamometer.

\section{Resumo}

Introdução: A fadiga muscular é um fenômeno associado ao trabalho comum em esportes de resistência, testes físicos e em atividades diárias. Alguns testes podem ser diretamente afetados pelo efeito da fadiga muscular periférica, dentre estes a forç̧a de preensão manual (FPM) que é considerada a medida referência para avaliação da funcionalidade da mão. Objetivos: a) verificar o efeito da fadiga muscular periférica, entre as tentativas, durante a realização do teste de FPM com intervalo de recuperação de 60 segundos; b) analisar a existência da diferença em considerar como resultado final o valor médio obtido nas três tentativas ou o melhor resultado. Materiais e métodos: Foram medidos 1.279 homens seguindo-se a metodologia padrão e utilização de um dinamômetro hidráulico manual. Resultados: Houve diferença estatística significativa $(P<0,05)$ na mão dominante entre todas as tentativas. Primeira (46,5 $\pm 8,6 \mathrm{Kgf})$, segunda $(46,4 \pm 8,5 \mathrm{Kgf})$, terceira $(46,1 \pm 8,6$ $\mathrm{Kgf})$ e, na mão não dominante entre todas as tentativas, primeira (44,9 $\pm 8,4 \mathrm{Kgf})$, segunda (44,5 $\pm 8,3 \mathrm{Kgf}) e$ terceira $(44,0 \pm 8,3 \mathrm{Kgf})$, bem como foi observada diferença estatística significativa $(P<0,05)$ entre as duas formas de se considerar o resultado final. Na mão dominante a média das três tentativas foi de (46,3 $\pm 8,3 \mathrm{Kgf})$ e, considerando o melhor resultado (48,1 $\pm 8,5 \mathrm{Kgf})$, já na mão não dominante foram $(44,5 \pm 8,2 \mathrm{Kgf})$ e $(46,0$ $\pm 8,2 \mathrm{Kgf}$ ) respectivamente. Conclusão: A fadiga muscular periférica interfere diretamente no resultado final, indicando redução significativa no decorrer da avaliação. $O$ melhor resultado, frequentemente, é obtido na primeira tentativa, sendo indicado considerar como resultado final o maior valor obtido.

Palavras-chave: Contração muscular. Fadiga muscular. Força da mão. Dinamômetro de força muscular.

\section{Introduction}

Muscle fatigue is a phenomenon associated with physical work. It is common in endurance sports, physical fitness tests and daily activities $(1,2,3)$. Usually, two types of muscle fatigue are defined: central and peripheral. The first is characterized by progressive speed and frequency reduction of voluntary drive to motoneurons during exercise. The second is described as the result from changes localized below the neuromuscular junction, which cause decreased efficiency of the contractile units of the muscle (2).

In this sense, some physical tests may be directly influenced by the effects of peripheral muscle fatigue, such as those employed in the studies of Albuquerque et al. (4) and Rizzi et al. (5), and the handgrip strength (HGS) test. The latter is considered as a baseline measure for assessing the functionality of the hand (6). It is often used in the analysis of clinical conditions such as rheumatoid arthritis or muscular dystrophy, to test the efficiency of different surgical procedures or treatments, as well as to determine the physical work capacity of patients with lesions on hands or arms $(7,8,9,10)$.

In addition to these uses, the HGS test is recommended and applied by nutritionists as a functional index of nutritional status (11) to evaluate the effectiveness of dietary intervention in hospitalized patients (12); by physical education teachers in batteries of tests used in competitions, for identifying sporting talents (13) and assessing methods and training in athletes $(13,14,15,16)$; or by physical therapists for setting treatment goals, monitoring progress and assessing clinical situations in which muscle strength is directly affected $(17,18)$. In gener$\mathrm{al}$, health professionals also make use of this method to verify the relative effects of age on muscle strength in children, youth, adults and elders. The HGS test is considered to be an indicator of an individual's overall strength status $(6),(10,11)$.

Since a broad range of researchers and professionals from different fields of expertise make use of the HGS test, several studies have been conducted and highlighted the validity, accuracy and reliability 
of this test and other equipments (13). In addition to these factors, a set of methodological recommendations are proposed in order to standardize the types of measurements used in different studies, which would allow for their comparison. These recommendations involve: the positioning of the body for performing the test, instructions, duration of contraction, pre-test warm-up, position of the handle, number of measurements, period of rest between trials and value to be considered as the final result of the test $(13),(19,20)$.

In this sense, not all of these recommendations were studied separately or together, and there is no consensus among researchers on all these points. Regarding the number of measurements, the recommendation is to perform three trials, made alternately in each arm and starting with the right side, with a 15-60 seconds period of rest between trials, the latter being more prevalent. Another recommendation that requires further investigations is which value should be considered as the result of the test: the mean value obtained in the three trials or the highest value recorded (13), (19).

Given the above, the objectives of this study are: a) to verify the effect of peripheral muscle fatigue (between trials) during the testing of HGS, with a 60 -second recovery interval; b) to analyze whether there are differences in considering the mean value obtained in three trials or the best result as the final result.

\section{Materials and methods}

This is a cross-sectional observational study. 1,400 men were initially assessed. 121 were considered outliers and excluded from the study after checking the distribution of the HGS values in all attempts in the dominant and non-dominant hands. Therefore, the final sample comprised 1,279 men. Exclusion criteria included: any restriction of movement in the arms or legs, self-reported history of inflammatory joint disease, neurological disorder, or any kind of abnormality in the upper limb.

In order to characterize the sample, we carried out anthropometric measurements, including body mass (kg, accuracy $\pm 100 \mathrm{~g}$ ) and height (cm, accuracy \pm $1 \mathrm{~cm}$ ). The sample was also characterized by age and hand dominance. All data collections were performed in the Human Performance Laboratory (LAPEH) of the Department of Physical Education, Federal University of Viçosa, in a controlled environment with an average temperature of $21.4 \pm 0.8^{\circ} \mathrm{C}$ and relative air humidity of $71.4 \pm 5.3 \%$. All measurements were performed in both hands. The subjects were at rest and had not made any physical effort before the first measurement. The choice of the dominant hand was self-reported and defined as the one preferably used to carry out daily activities such as writing, eating and handling heavy objects. The manual hydraulic dynamometer Jamar ${ }^{\circledR}$ (PC5030J1, Fit Systems Inc, Calgary, Canada) was used to perform the test.

For the positioning of the arm, we followed the guidelines of the American Society of Hand Therapists (19). The handle of the dynamometer was maintained in the second position for all subjects. Three maximal 3-minute trials were made alternately, with 60 -second intervals between trials. The same voice tone was used during the instructions period and no verbal encouragement was provided. Results were recorded in kilograms force (kgf).

This study was conducted in accordance with ethical standards and was approved by the Ethics Committee of the Federal University of Viçosa, Brazil (protocol number 40928260625). All participants signed an informed consent form (according to Resolution 196/96 of the National Health Council).

We initially used descriptive statistics (mean and standard deviation) to describe the results. The Shapiro-Wilk test was used to assess the normality of the data and the Friedman test followed by post hoc Dunn's test was used to verify the effect of muscle fatigue between trials. The Wilcoxon test was used to compare the mean of three trials against the best result, and to compare the values found for both hands. When necessary, the chi-square test was used to verify the difference between frequencies. The level of significance was set at $p<0.05$. All analyzes were performed using the Sigmaplot ${ }^{\circledR}$ statistical software (version 11.0).

\section{Results}

The mean age of the sample was $27.5 \pm 10.1$ years (14-60 years). Mean height was $173.6 \pm 6.4 \mathrm{~cm}(150.0$ to $192.0 \mathrm{~cm})$. Mean body mass index was $68.9 \pm 10.3$ $\mathrm{kg}$ (45.0 to $105.0 \mathrm{~kg}$ ) and body mass index $22.9 \pm 2.8$ $\mathrm{kg} / \mathrm{m}^{2}$ (13.7 to $35.6 \mathrm{Kg} / \mathrm{m}^{2}$ ). The right hand was indicated as dominant in 1,200 individuals (93.8\%), 
while 79 (6.2\%) subjects self-declared themselves as left-handed.

Table 1 shows the results of the HSG test for the first, second and third trials in the dominant and in the non-dominant hands, and the frequency at which the best result was achieved among the different trials. Table 2 shows the final results, according to the mean of the three trials or the maximum value found.

\section{Discussion}

When multiple maximal efforts are performed in a short period of time, the chances of onset of muscle fatigue increase. Thus, in the HGS test, the number of measurements taken and the interval time directly influence the final result. In the present study, the main results indicate that there is a significant difference in the dominant hand among the trials. This indicates that the subject assessed could not repeat the same strength levels due to successive wear. A similar result was observed for the non-dominant hand. These findings are contrary to the study by Mathiowetz (21), which found no significant difference between trials with 60 -second intervals.
Our results indicate that the recovery time of 60 seconds between trials does not seem to be enough for the subjects to maintain or improve their performances. However, when analyzing the percentage of reduction of HGS levels between trials, we found that, in the dominant hand, from the first to the second trial and from the second to the third trial, there were reductions of only $0.2 \%$ and $0.6 \%$, respectively. In the non-dominant hand reductions between trials were $0.9 \%$ and $1.1 \%$, respectively. Thus, when this analysis is performed, it does seem that the time of interval between trials is enough to avoid the occurrence of great reductions in the mean HGS levels of the entire sample. Trossman and $\mathrm{Li}(22)$ investigated the effect of different recovery times $-60,30$ and 15 seconds - and found no significant difference among them. Since the total time of a test directly affects the dynamics of research, especially when evaluating large populations or in daily practice, it is extremely important that tests are performed as quickly as possible, without making measurement errors. Thus, we believe that the 60 -second interval is sufficient to avoid great differences between trials and represents no major compromise from a practical standpoint.

Table 1 - HGS found at the first, second and third trials, and frequency at which the best result was achieved among the different trials

\begin{tabular}{clccccc}
\hline & \multicolumn{2}{c}{ Trial results } & & \multicolumn{2}{c}{ Frequency of the best result } \\
\cline { 1 - 3 } \cline { 6 - 7 } Hand & Dominant & Non-dominant & & Dominant & Non-dominant \\
\hline $1^{\text {st }}$ & $46.5 \pm 8.6^{*}$ & $44.9 \pm 8.4 \dagger$ & & $665(52.0 \%) \dagger$ & $759(59.3 \%) \dagger$ \\
$2^{\text {nd }}$ & $46.4 \pm 8.5^{* *}$ & $44.5 \pm 8.3 \dagger \dagger$ & & $346(27.1 \%) \dagger \dagger$ & $314(24.6 \%) \dagger \dagger$ \\
$3^{\text {rd }}$ & $46.1 \pm 8.6$ & $44.0 \pm 8.3$ & & $268(21.0 \%)$ & $206(16.1 \%)$ \\
\hline
\end{tabular}

Note: Data presented as mean \pm mean deviation. ${ }^{*} p<0.05$ for the dominant hand $1{ }^{\text {st }} v s$. other trials; ${ }^{* *} p<0.05$ for the dominant hand $2^{\text {nd }} V S$. other trials; $\uparrow p<0.05$ for the non-dominant hand $1^{\text {st }} v s$. other trials; $\uparrow \uparrow p<0.05$ for the dominant hand $2^{\text {nd }} v s$. other trials; $\uparrow p<0.05$ for the dominant and the non-dominant hands $1^{\text {st }} v s$. other trials; $\uparrow \uparrow p<0.05$ for the dominant and the non-dominant hands $2^{\text {nd }} v s$. other trials. Source: Research data.

Another result that can be highlighted is that both for the dominant and the non-dominant hand, more than $50 \%$ of HGS best results are achieved at the first trial. However, the other trial results should not be discarded, since relevant percentages are achieved at the second and third trials. When comparing the mean of the three trials with the best result obtained among them (Table 2), a statistically significant difference between these two ways of considering the final result was found. This was also observed in a study by Coldham et al. (23). Thus, as it is a maximal test, we believe that the highest value recorded among the three trials should be considered as the final result.

It has been reported in the literature that the HGS of the dominant hand is approximately $10 \%$ higher than the non-dominant hand $(24,25)$. However, in our study 
we found that this difference was only $4.3 \%$, when considering the best result. This indicates that this rule is not applicable to this study population, which was also found in the studies by Novaes et al. (20) and Jarjour et al. (26). When comparing both the mean of the three trials and the best result of the dominant hand with the non-dominant hand, we could note that there is a statistically significant difference between the two hands. The same was observed by Adedoyin et al. (27) and Werle et al. (28). This indicates, thus, that dominance directly interferes in the final result.

The results of our study were higher than those found by Caporrino et al. (29) for the same age group and using the same methodology. Comparison with other studies in the Brazilian population is hampered by methodological differences. It is important to stress that the methodological characteristics presented here, as well as the suggested recovery time between trials ( 60 seconds), and the fact that the best result obtained in the test is considered, should be taken into consideration in researches involving the assessment of HGS in any kind of population: in individuals with Down syndrome (30), in athletes (13), or in studies on aging and sarcopenia $(31,32)$. A meticulous and standardized methodological action helps researchers in the correct interpretation and comparison of results.

Table 2 - HGS test results for the mean of the three trials and the best result

\begin{tabular}{ccc}
\hline & Dominant hand & Non-dominant hand \\
\hline Mean of the $\mathbf{1}^{\text {st }}, \mathbf{2}^{\text {nd }}, 3^{\text {rd }}$ & $46.3 \pm 8.3^{*} \dagger$ & $44.5 \pm 8.2^{*}$ \\
Best Result & $48.1 \pm 8.5 \dagger$ & $46.0 \pm 8.2$ \\
\hline
\end{tabular}

Note: * Significant difference $(p<0.05)$ between the mean of the three trials and the best result for the dominant and the non-dominant hand. † Significant difference $(p<0.05)$ between the dominant and the non-dominant hand.

Source: Research data.

\section{Conclusion}

We observed that during the testing of HGS, peripheral muscle fatigue directly interferes on the end result, indicating significant reduction in the course of the assessment. The best result is often obtained at the first trial, which indicates that the best result obtained on the test should be considered as the final result, instead of the mean of the three trials.

\section{References}

1. Silva BARS, Martinez FG, Pacheco AM, Pacheco I. Efeitos da fadiga muscular induzida por exercícios no tempo de reação muscular dos fibulares em indivíduos sadios. Rev Bras Med Esporte. 2006;12(2):85-9.

2. Ribeiro F, Oliveira J. Efeito da fadiga muscular local na propriocepção do joelho. Fisioter Mov. 2008;21(2):71-83.

3. Barbosa FSS, Almeida CCR, Gonçalves M. Análise espectral do sinal eletromiográfico do músculo eretor da espinha obtido do teste de Sorensen. Fisioter Mov. 2010;23(4):575-83.
4. Albuquerque CV, Maschio JP, Gruber CR, Souza RM, Hernandez S. Efeito agudo de diferentes formas de aquecimento sobre a força muscular. Fisioter Mov. 2011;24(2):221-9.

5. Rizzi PRS, Leal RM, Vendrusculo AP. Efeito da hidrocinesioterapia na força muscular e na flexibilidade em idosas sedentárias. Fisioter Mov. 2010;23(4):535-43.

6. Gunther CM, Burger A, Rickert M, Crispin A, Schulz CU. Grip strength in healthy caucasian adults: reference values. J Hand Surg Am. 2008;33(4):558-65.

7. Jupiter JB, Marent-Huber M. Operative management of distal radial fractures with 2.4-millimeter locking plates. A multicenter prospective case series. J Bone Joint Surg Am. 2009;91(1):55-65.

8. Barbieri CH, Mazzer N, Elui VMC, Fonseca MCR. Resultados funcionais da artrodese do punho. Acta Ortop Bras. 2002;10(1):17-24.

9. Figueiredo I, Sampaio R, Mancini M, Nascimento M. Ganhos funcionais e sua relação com os componentes de função em trabalhadores com lesão de mão. Rev Bras Fisioter. 2006;10(4):421-7. 
10. van-den-Beld WA, van-der-Sanden GA, Sengers RC, Verbeek AL, Gabreels FJ. Validity and reproducibility of the Jamar dynamometer in children aged 4-11 years. Disabil Rehabil. 2006;28(21):1303-9.

11. Norman K, Stobaus N, Gonzalez MC, Schulzke JD, Pirlich M. Hand grip strength: outcome predictor and marker of nutritional status. Clin Nutr. 2011;30(2):135-42.

12. Schlüssel MM, Anjos LA, Kac G. A dinamometria manual e seu uso na avaliação nutricional. Rev Nutr. 2008;21(2):233-5.

13. Fernandes AA, Marins JCB. Teste de força de preensão manual: análise metodológica e dados normativos em atletas. Fisioter Mov. 2011;24(3):567-78.

14. Fernandes AA, Marins JCB. Estudo compartivo da força de preensão manual em diferentes modalidades esportivas. Col Pes Educ Fís. 2005;4(1):387-90.

15. Brito CJ, Gatti K, Natali AJ, Costa NMB, Silva CHO, Marins JCB. Estudo sobre a influência de diferentes tipos de hidratação na força e potência de braços e pernas de judocas. Fit Perf J. 2005;4(5):274-9.

16. Oliveira M, Moreira D, Godoy JRP, Cambraia AN. Avaliação da força de preensão palmar em atletas de jiu-jitsu de nível competitivo. R Bras Ci e Mov. 2006; $14(3): 63-70$.

17. Lima G, Barboza E, Alfieri F. Análise da funcionalidade e da dor de indivíduos portadores de síndrome do impacto, submetidos à intervenção fisioterapêutica. Fisioter Mov. 2007;20(1):61-9.

18. Sobral MKM, Silva PG, Vieira RAG, Siqueira GRd. A efetividade da terapia de liberação posicional (TLP) em pacientes com cervicalgia. Fisioter Mov. 2010; 23(4):513-21.

19. Bohannon RW, Peolsson A, Massy-Westropp N, Desrosiers J, Bear-Lehman J. Reference values for adult grip strength measured with a Jamar dynamometer: a descriptive meta-analysis. Physiotherapy. 2006;92(1):11-5.

20. Novaes RD, Miranda AS, Silva JO, Tavares BVF, Dourado VZ. Equações de referência para a predição da força de preensão manual em brasileiros de meia idade e idosos. Fisioter Pesqui. 2009;16(3):217-22.

21. Mathiowetz V. Effects of three trials on grip and pinch strength measurements. J Hand Ther. 1990; 3(4):195-8.
22. Trossman P, Li P. The effect of the duration of intertrial rest periods on isometric grip strength performance in young adults. Occup Ther J Res. 1989;9(6):362-78.

23. Coldham F, Lewis J, Lee H. The reliability of one vs. three grip trials in symptomatic and asymptomatic subjects. J Hand Ther. 2006;19(3):318-27.

24. Petersen P, Petrick M, Connor H, Conklin D. Grip strength and hand dominance: challenging the $10 \%$ rule. Am J Occup Ther. 1989;43(7):444-7.

25. Crosby CA, Wehbé MA, Mawr B. Hand strength: normative values. J Hand Surg Am. 1994;19(4):665-70.

26. Jarjour N, Lathrop JA, Meller TE, Roberts KS, Sopczak JM, Van-Genderen KJ, et al. The $10 \%$ rule: grip strength and hand dominance in a factory population. Work. 1997;8(1):83-91.

27. Adedoyin RA, Ogundapo FA, Mbada CE, Adekanla BA, Johnson OE, Onigbinde TA, et al. Reference Values for handgrip strength among healthy adults in Nigeria. Hong Kong Physiother J. 2009;27(1):21-9.

28. Werle S, Goldhahn J, Drerup S, Simmen BR, Sprott H, Herren DB. Age- and gender-specific normative data of grip and pinch strength in a healthy adult Swiss population. J Hand Surg Eur Vol. 2009;34(1):76-84.

29. Caporrino FA, Faloppa F, Dos-Santos JBG, Réssio C, Soares FHDC, Nakachima LR, et al. Estudo populacional da força de preensão palmar com dinamômetro Jamar. Rev Bras Ortop. 1998;33(2):150-4.

30. Gianlorenço ACL, Ide D, Braccialli LMP. Influência da textura na preensão de indivíduos com Síndrome de Down. Fisioter Mov. 2010;23(2):229-38.

31. Pícoli TS, Figueiredo LL, Patrizzi LJ. Sarcopenia e envelhecimento. Fisioter Mov. 2011;24(3):455-62.

32. Fernandes AA, Silva CD, Vieira CD, Marins JCB. Validade preditiva de equações de referência para força de preensão manual em homens brasileiros de meia idade e idosos. Fisioter Pesqui. 2012;19(4):351-56.

Received: 01/02/2014 Recebido: 02/01/2014

Approved: 07/03/2014 Aprovado: 03/07/2014 